\title{
Liming and Fertilization on the Growth of Eucalyptus benthamii and Eucalyptus dunnii in Brazil
}

\author{
Diego Pereira da Rosa (D, Marcio Carlos Navroski (D, Mariane De Oliveira Pereira (D), \\ Geedre Adriano Borsoi $\mathbb{D}^{\mathbb{D}}$, Bruno Nascimento $\mathbb{D}$, Ramon Silveira De Andrade $\mathbb{D}$, \\ and Carolina Moraes (iD
}

Department of Forest Engineering, State University of Santa Catarina (UDESC), Luiz de Camões Avenue, 2090, Lages, SC 88520000, Brazil

Correspondence should be addressed to Marcio Carlos Navroski; marcio.navroski@udesc.br

Received 25 August 2020; Revised 9 October 2020; Accepted 20 October 2020; Published 30 October 2020

Academic Editor: Qing Lai Dang

Copyright ( 2020 Diego Pereira da Rosa et al. This is an open access article distributed under the Creative Commons Attribution License, which permits unrestricted use, distribution, and reproduction in any medium, provided the original work is properly cited.

\begin{abstract}
The use of mineral fertilizers has shown substantial productivity gains for the vast majority of Eucalyptus forests. The objective of the present work is to evaluate the response of Eucalyptus benthamii and Eucalyptus dunnii at 48 months of age, to different doses of limestone, soluble NPK, and natural phosphates. The experiment was conducted in a plantation located in South Brazil. The experimental design was a randomized block with three replications, and the treatments consisted of combinations of doses of natural phosphate (NP) $\left(0,400,600\right.$, and $800 \mathrm{~kg} \mathrm{ha}^{-1}$ of Gafsa reactive NP $\left.\mathrm{P}_{2} \mathrm{O}_{5}\right)$, limestone $\left(0,3,5,6\right.$, and $10 \mathrm{Mg}^{-1}$ of dolomitic limestone), and mineral fertilizer-NPK $\left(0,100,133\right.$, and $167 \mathrm{~kg} \mathrm{ha}^{-1}$ of mixed mineral fertilizer 6-30-6). Height and diameter measurements were taken after 48 months. There was a positive response with the increase of NPK fertilizer dose, and the dose where the highest averages were obtained was $167 \mathrm{~kg} \mathrm{ha}^{-1}$. The doses of NP had significant effects on the increase of the variables up to $600 \mathrm{~kg} \mathrm{ha}^{-1}$, also the averages decreased with the increase of the dosage. For liming, positive results were observed from its absence to the maximum dose, justifying its use in minimum dose in order to supply the necessary amounts of $\mathrm{Ca}$ and $\mathrm{Mg}$ in the soil. The use of NPK, natural phosphate, and limestone is recommended, causing an increase in the growth of both species of Eucalyptus studied.
\end{abstract}

\section{Introduction}

The introduction of species from other regions is a process that needs studies aimed at assessing their adaptability and survival, as well as their reflexes on economic productivity. A combination of several factors is required for the establishment of productive forests, such as site-adapted genetic materials, favorable soil and climate conditions, proper management, and high-quality seedlings [1].

The need for fertilization in forest species comes from the fact that the soil is not always able to provide all the nutrients in quantity that the plants need for proper growth, and the amount depends on the nutritional needs, soil fertility, reaction of fertilizers with soil, and fertilizer efficiency. Proper nutrition in Eucalyptus plantations is essential for the establishment of high-yielding forests [2].
Eucalyptus species are considered nutrient-demanding, mainly phosphorus in the early phase and potassium in the juvenile and adult phase [3]. Given this feature, along with the fact that they are under subtropical conditions, it is relevant to promote rapid early development with gains in height and diameter, so that plants reach a size where frost damage is minimized. However, regarding nitrogen fertilization, Sette et al. [4] did not obtain increment for E. grandis, as well as no changes in wood structure.

Most Brazilian soils have inadequate chemical characteristics for intensive production, among them a high natural acidity, making it necessary to use limestone for its suitability, increasing the $\mathrm{pH}$ and calcium and magnesium levels in the soil, and allowing the full development of the culture [5]. According to Barros et al. [6], liming calcium is the second nutrient most absorbed by most forest species. The 
most accumulated nutrients in components exported from the Eucalyptus production area are $\mathrm{Ca}$ and $\mathrm{Mg}$, placed in order, with Ca occupying the first place, with approximately $75 \%$ of this element exported from the site with the harvest. Over several years of cultivation, nutritional deficiency can be promoted for plants and limits the productivity of future cycles due to Ca depletion [7]. In addition, nutritional imbalances may be produced by providing inadequate $\mathrm{Ca}^{2+}$ and $\mathrm{Mg}^{2+}$ ratios, which may induce plant deficiency and compromise growth.

Fertilization can increase the growth of E. benthamii and E. dunnii forests, resulting in an increased final yield and may even reduce the rotational cycle. There is a direct relationship between the different doses of liming, phosphating, and NPK with the growth of Eucalyptus species. In view of this, it is expected that different growth behaviors will be expressed as a function of fertilizer doses, and the higher the dose, the higher the growth of dendrometric variables.

Thus, the objective of the study was to quantify the growth of E. benthamii and E. dunnii, in response to fertilization, for the different doses of dolomitic limestone, reactive natural phosphate, and NPK, aiming to define the specific fertilization management for each studied species.

\section{Materials and Methods}

2.1. Study Area. The study was carried out in Rio Negrinho (latitude $26^{\circ} 06^{\prime} 41^{\prime \prime}$ south and longitude $49^{\circ} 48^{\prime} 19^{\prime \prime}$ west), located in the microregion of the northern plateau of Santa Catarina State (Brazil). With an average altitude of $800 \mathrm{~m}$ above the sea level, the municipality presents regular surface and plateau relief, with hills of small altimetric amplitude.

Regarding the climate, in the Köeppen classification, the northern Santa Catarina plateau is Cfb (constantly humid temperate climate, no dry season, with cool summer). The average annual temperature ranges from $15.0^{\circ} \mathrm{C}$ to $17.0^{\circ} \mathrm{C}$, with average maximum temperatures ranging from $24.0^{\circ} \mathrm{C}$ to $26.6^{\circ} \mathrm{C}$ and minimum from $10.8^{\circ} \mathrm{C}$ to $11.8^{\circ} \mathrm{C}$. The average annual precipitation is $1720 \mathrm{~mm}$, with maximum and minimum of $2500 \mathrm{~mm}$ and $1082 \mathrm{~mm}$, respectively. The relative humidity can vary from $80.0 \%$ to $86.2 \%$ [8]. Considering the hydraulic demand of Eucalyptus, which is $800-1,200 \mathrm{~mm}$ [9], the study area has the amount of rain necessary to meet the average requirements of the genus.

Prior to the implementation of the experiment, no natural corrective or phosphates had been used in the field, only base fertilization in this area, which was cultivated with E. viminalis in the first planting cycle, planting in 1983 and clear-cutting in 2011.

Soil composite samples were collected in the $0-20 \mathrm{~cm}$ layer to characterize it in the experimental area (Table 1). Chemical analyses were performed according to the methodology described by Tedesco et al. [10] by the Soil Routine Analysis Laboratory of the Department of Soils and Natural Resources of Santa Catarina State University, Lages, SC (Brazil). The soil of the experiment site was classified as Humic Cambisol (Cambisols).
TABle 1: Chemical and physical characteristics of the soil in the $0-20 \mathrm{~cm}$ depth layer of the study area.

\begin{tabular}{lcc}
\hline Attributes & Values & Interpretation* \\
\hline $\mathrm{pH} \mathrm{H} \mathrm{H}_{2}^{(1)}(1: 1)$ & 4.28 & No pH for reference** \\
$\mathrm{SMP} \mathrm{buffer}^{(2)}\left(\mathrm{cmol}_{\mathrm{c}} \mathrm{dm}^{-3}\right)$ & 4.20 & - \\
$\mathrm{Mg}^{(2)}\left(\mathrm{cmol}_{\mathrm{c}} \mathrm{dm}^{-3}\right)$ & 0.88 & $\geq 4.0 \mathrm{cmol}_{\mathrm{c}} \mathrm{dm}^{-3}$ \\
$\mathrm{Al}^{(2)}\left(\mathrm{cmol}_{\mathrm{cm}} \mathrm{dm}^{-3}\right)$ & 0.76 & $\geq 1.0 \mathrm{cmol}_{\mathrm{c}} \mathrm{dm}^{-3}$ \\
$P \mathrm{Mehlich}^{(2)}\left(\mathrm{mg} \mathrm{dm}^{-3}\right)$ & 4.64 & - \\
$K^{(2)}\left(\mathrm{mg} \mathrm{dm}^{-3}\right)$ & 0.72 & $\geq 15.1 \mathrm{mg} \mathrm{dm}^{-3}$ \\
$\mathrm{OM}(\%)$ & 73.80 & $\geq 106 \mathrm{mg} \mathrm{dm}^{-3}$ \\
Effective CEC $\left(\mathrm{cmol}_{\mathrm{c}} \mathrm{dm}^{-3}\right)$ & 3.45 & $\geq 5.00 \%$ \\
$\mathrm{CEC} \mathrm{pH} 7.0\left(\mathrm{cmol}_{\mathrm{c}} \mathrm{dm}^{-3}\right)$ & 36.36 & - \\
Basis saturation $(\%)$ & 5.00 & $15.1 \mathrm{a} 30.0$ \\
Al saturation $(\%)$ & 71.84 & - \\
Clay $(\%)$ & 18.50 & - \\
\hline
\end{tabular}

${ }^{1}$ Methodology used by Tedesco et al. [10]; OM, organic matter. *Values are subjected to interpretation. ${ }^{* *}$ Culture tolerant to soil acidity and has no $\mathrm{pH}$ for reference.

2.2. Experimental Design and Treatments. The experiment was set up in a randomized block design with three replications of 15 trees each. The treatments consisted of combinations of doses of natural phosphate $(0,400,600$, and $\left.800 \mathrm{~kg} \mathrm{ha}^{-1}\right)$, limestone $\left(0,3,5,6\right.$, and $\left.10 \mathrm{Mg} \mathrm{ha}^{-1}\right)$, and NPK mineral fertilizer $\left(0,100,133\right.$, and $\left.167 \mathrm{~kg} \mathrm{ha}^{-1}\right)$, at planting fertilization, for E. benthamii and E. dunnii. E. benthamii seedlings of seminal origin produced in the region of São Bento do Sul, SC (Brazil), and clonal plants of E. dunnii produced in the region of Canoinhas, SC (Brazil), were used. For both species, the seedlings planted were approximately $30 \mathrm{~cm}$ height and had shoot diameter greater than $2 \mathrm{~mm}$.

The amounts of nutrients used in the experiment were determined from soil analysis performed before planting. The $400 \mathrm{~kg}$ dosage of natural phosphate is the standard dosage of the company where the study was conducted, with $800 \mathrm{~kg}$ being double the dosage and 600 the average of the two doses. The NP used was the Tunisia-branched Gafsa reactive (NPGR) (28\% total $\left.\mathrm{P}_{2} \mathrm{O}_{5}\right)$.

For the limestone factor, the company uses $3.5 \mathrm{Mg} \mathrm{ha}^{-1}$ as the standard farm dosage. The dosage of $10 \mathrm{Mg} \mathrm{ha}^{-1}$ is almost half the dosage of $19 \mathrm{Mg} \mathrm{ha}^{-1}$, recommended by the Rede Oficial de Laboratórios de Análise de Solos (ROLAS) (Official Network of Soil Analysis Laboratories) [11], and as intermediate dose was used, $6 \mathrm{Mg} \mathrm{ha}^{-1}$. For NPK, the dose of $133 \mathrm{~kg} \mathrm{ha}^{-1}$ is recommended by the interpretation of soil analysis, with $167 \mathrm{~kg} \mathrm{ha}^{-1}$, the maximum dose, and $100 \mathrm{~kg}$ $\mathrm{ha}^{-1}$, the minimum dose. The source of NPK was mixed mineral fertilizer with formulation 6-30-6 (NPK), providing the amount of $6 \mathrm{~kg} \mathrm{ha}^{-1}$ of $\mathrm{N}$ and $\mathrm{K}_{2} \mathrm{O}$ and $30 \mathrm{~kg} \mathrm{ha}^{-1}$ of $\mathrm{P}_{2} \mathrm{O}_{5}$ for $100 \mathrm{~kg} \mathrm{ha}^{-1}$ fertilizer dose, $8 \mathrm{~kg} \mathrm{ha}^{-1}$ of $\mathrm{N}$ and $\mathrm{K}_{2} \mathrm{O}$ and $40 \mathrm{~kg} \mathrm{ha}^{-1}$ of $\mathrm{P}_{2} \mathrm{O}_{5}$ for $133 \mathrm{~kg} \mathrm{ha}^{-1}$ of fertilizer, and $10 \mathrm{~kg} \mathrm{ha}^{-1}$ of $\mathrm{N}$ and $\mathrm{K}_{2} \mathrm{O}$ and $50 \mathrm{~kg} \mathrm{ha}^{-1}$ of $\mathrm{P}_{2} \mathrm{O}_{5}$ for $167 \mathrm{~kg} \mathrm{ha}^{-1}$ of fertilizer.

First, cultural treatments were made in the area in accordance with the company's operational plan. Operations began in November 2012 with the cleaning of the area by mechanized mowing and chemical weeding in the total area. The tillage was mechanized, performed in minimum 
cultivation with subsoiling at $45-50 \mathrm{~cm}$ deep in the planting line, with spacing of $3.0 \mathrm{~m}$ between the rows. After subsoiling, dolomitic limestone ( $80 \%$ PRNT) was applied according to the treatments.

The planting, the application of NP, and the fertilization of planting were carried out in January 2013. The planting was performed manually in spacing of $3 \times 3 \mathrm{~m}$, and the NP was filleted over the subsoiling line. There was an application of $500 \mathrm{~mL}$ of hydrogel per planting pit. Planting fertilization was carried out in two lateral "pits" per plant, at a distance of $10-15 \mathrm{~cm}$ from them, using manual fertilizers adjusted at the dosages fixed in the treatments.

Coverage fertilization was carried out two months after planting, along with the surface replanting, in the crown projection, at a dose of $133 \mathrm{~kg} \mathrm{ha}^{-1}$ of mineral fertilizer with formulation 20-00-20 (N-P-K), providing the amount of $27 \mathrm{~kg} \mathrm{ha}^{-1}$ of $\mathrm{N}$ and $\mathrm{K}_{2} \mathrm{O}$. Coverage fertilization was performed at the same dose for all plots.

The fight against leaf-cutting ants was carried out by applying $4 \mathrm{~kg} \mathrm{ha}^{-1}$ of formicide bait at the time of planting and 20 days after planting. Ten months after planting, a mechanized mowing was performed between the rows to control weed competition.

2.3. Data Collection and Analysis. The dendrometric data of total tree height $(\mathrm{m})$ and BHD diameter at breast height $(\mathrm{cm})$ were collected with the help of the Haglöf and Suta clinometer, respectively, in February 2017. All diameters were collected within each portion and five heights. The other heights were estimated using a hypsometric equation, with the Kopezky-Gehrhadt model chosen for E. benthamii: $\mathrm{ht}=\beta 0+\beta 1 \cdot \mathrm{BHD}^{2}$, with a coefficient of determination (adjusted $R^{2}$ ) of 0.3983 ; estimate standard error (Syx\%) of $11.25 \%$; and coefficients $\beta 012.4166$ and $\beta 10.0178$. For E. dunnii, the model chosen was Schneider's ht $-1.3=\beta 0+\beta 1 \cdot \mathrm{BHD}$, with an adjusted $R^{2}$ of 0.5482 ; Syx $\%$ of 7.13 , and $\beta 05.3158$ and $\beta 10.6080$. The volume was calculated by the expression, $V=g * h * f$, where $V$ is the volume $\left(\mathrm{m}^{3}\right) ; g$ is the basal area $\left(\mathrm{m}^{2}\right) ; h$ is the height $(\mathrm{m})$; and $f$ is the artificial form factor considering 0.4624 [12]. After estimating the variables, the data were submitted to Tukey's means test at $5 \%$ error probability. The analyses were performed using the variations between the treatments (NPK, natural phosphate, and limestone) and the two species (E. benthamii and E. dunnii).

\section{Results}

3.1. Species and NPK. Regarding the diameter, for E. benthamii, the highest average was observed for $167 \mathrm{~kg}$ $\mathrm{ha}^{-1}$, not differing from $133 \mathrm{~kg} \mathrm{ha}^{-1}$ and being $13 \%$ higher in relation to the worst observed average, which was the control (Figure 1(a)). For E. dunnii, the highest average was presented by $167 \mathrm{~kg} \mathrm{ha}^{-1}$, which does not differ from $133 \mathrm{~kg}$ $\mathrm{ha}^{-1}$. The lowest average was presented by the control, being $21 \%$ smaller, not differing from $100 \mathrm{~kg} \mathrm{ha}^{-1}$.

There was a statistical difference for treatments in E. benthamii in relation to height, where the lowest result was observed for the control, with an average of $37 \%$ lower compared to the average of the other treatments (Figure 1(b)). For dosages of 100, 133, and $167 \mathrm{~kg} \mathrm{ha}^{-1}$, there were no differences. For $E$. dunnii, the lowest mean height was also observed for the control, being 19\% lower, not differing from $100 \mathrm{~kg} \mathrm{ha}^{-1}$. The highest averages were observed with $133 \mathrm{~kg} \mathrm{ha}^{-1}$ and $167 \mathrm{~kg} \mathrm{ha}^{-1}$.

For the volume in E. benthamii, the lowest average was presented by the control, differing from all other treatments (Figure 1(c)). The highest average was presented by $167 \mathrm{~kg}$ $\mathrm{ha}^{-1}$, not differing from $133 \mathrm{~kg} \mathrm{ha}^{-1}$, and $63 \%$ higher than the lowest average observed. E. dunnii obtained the highest average volume for the treatment $167 \mathrm{~kg} \mathrm{ha}^{-1}$, while the lowest average obtained was for the control treatment, 53\% lower than the highest average, not differing from $100 \mathrm{~kg}$ $\mathrm{ha}^{-1}$.

3.2. Species and Natural Phosphate (NP). Regarding the means of treatments with NP for E. benthamii in relation to $\mathrm{BHD}$, the lowest mean observed was in the control treatment that did not differ from $400 \mathrm{~kg} \mathrm{ha}^{-1}$ (Figure 2(a)). The other treatments had the highest averages, $13 \%$ higher than the lowest average. For height (Figure 2(b)), the control also obtained the lowest average, being 37\% lower than the others, which did not differ from each other. For E. dunnii, the lowest mean was observed for the control, both in relation to BHD and in relation to height, being $18 \%$ and $23 \%$, respectively, lower than the other averages.

Regarding the volume, the highest average for E. benthamii was presented by $600 \mathrm{~kg} \mathrm{ha}^{-1}$, not differing from $0 \mathrm{~kg} \mathrm{ha}^{-1}$ and $800 \mathrm{~kg} \mathrm{ha}^{-1}$ (Figure 2(c)). The lowest average obtained was for the control treatment, which differed from the other averages, and was $62 \%$ lower than the best average. For E. dunnii, the treatment with $600 \mathrm{~kg} \mathrm{ha}^{-1}$ of NP also had the highest average; however, it differed from the other treatments. The lowest average was observed for the control treatment, which was $48 \%$ lower than the treatment with the highest average.

3.3. Species and Liming. For E. benthamii BHD, the control treatment presented the lowest average, $18 \%$ lower than the average of the other treatments (Figure 3(a)). For height, the same behavior was observed, with the control treatment obtaining the lowest average (Figure 3(c)). The other treatments showed no difference between them, being 38\% superior in relation to the control. Regarding volume, the lowest mean was also for the control, differing from the other averages. The highest average obtained was for $6 \mathrm{Mg} \mathrm{ha}^{-1}$, not differing from $0 \mathrm{Mg} \mathrm{ha}^{-1}, 61 \%$ higher than the lowest average obtained.

The mean BHD for E. dunnii did not differ for liming doses, being $19 \%$ higher when compared to the control with the lowest average (Figure 3(a)). Regarding height and volume (Figures 3(b) and 3(c)), the lowest average was observed for the control, $24 \%$ and $41 \%$, respectively, lower than the other fertilizers, which did not differ from each other. 


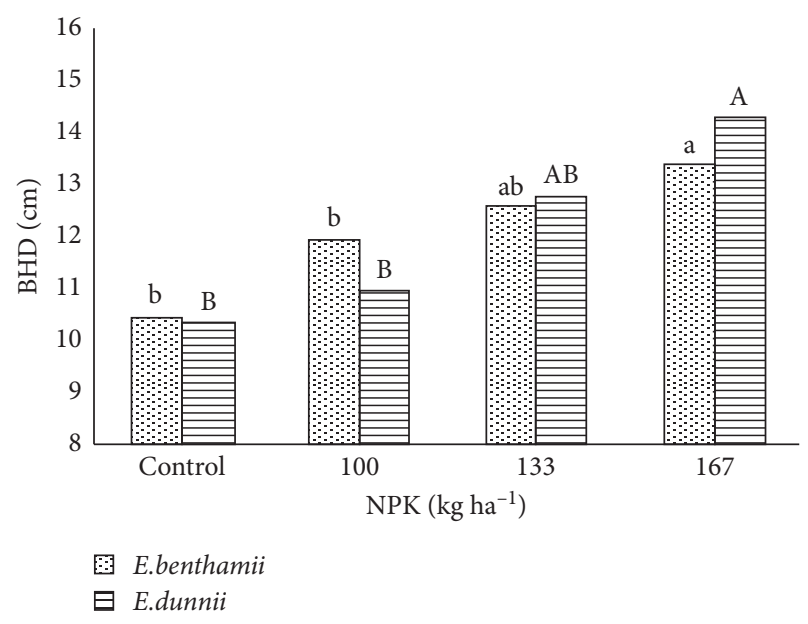

(a)

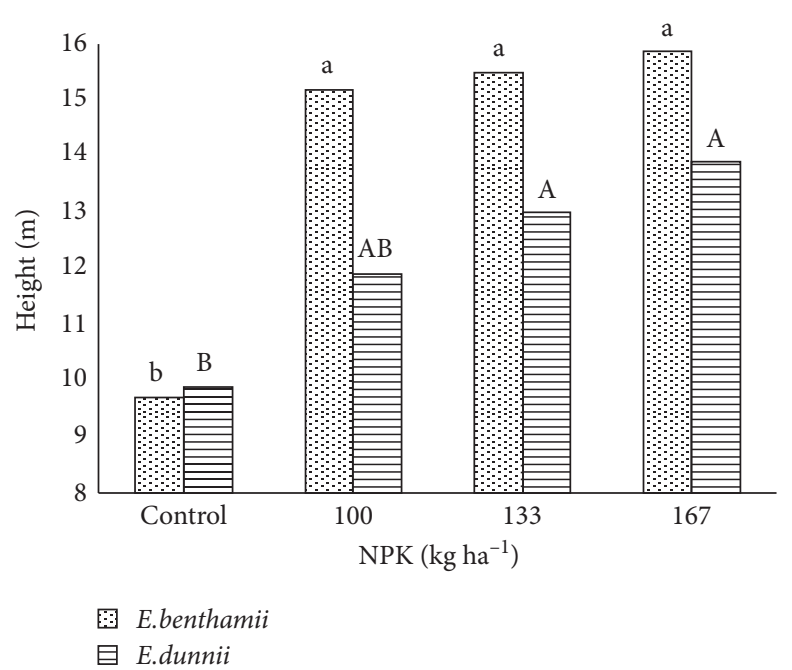

(b)

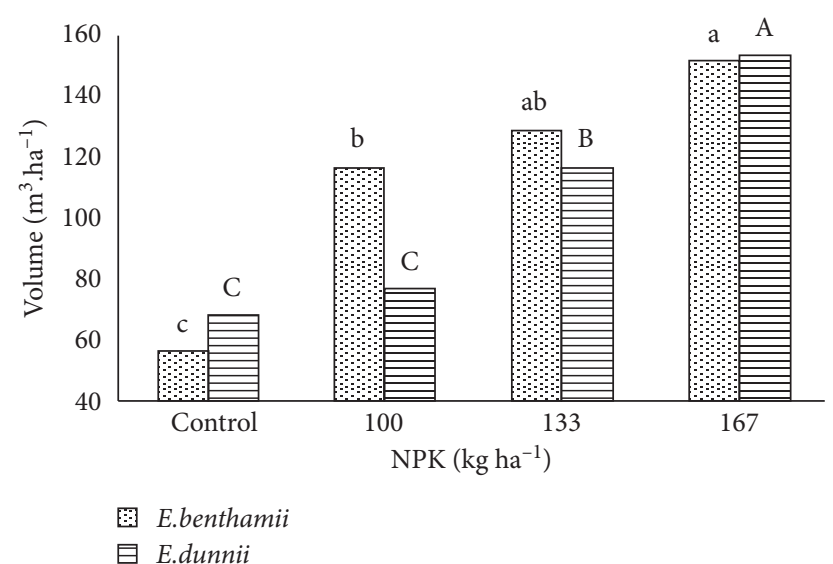

(c)

Figure 1: (a) Breast height diameter (BHD, cm), (b) height (m), and (c) volume $\left(\mathrm{m}^{3} \mathrm{ha}^{-1}\right)$ in Eucalyptus benthamii and Eucalyptus dunnii in relation to NPK fertilizing. Averages followed by the same letter, lower and uppercase, do not differ between them by the Tukey test at $5 \%$ probability. Lowercase letters compare fertilization in relation to E. benthamii. Uppercase letters compare fertilization in relation to E. dunnii.

3.4. Averages of Treatments and Species. Regarding BHD, there was no statistical difference between species averages for all treatments (Figure 4). For height, there was a statistical difference between the species, and the highest averages were obtained for E. benthamii, around 16\% higher when compared to the E. dunnii averages. The averages obtained for volume also present a statistical difference between species and behaved on an average 13\% higher for E. benthamii when compared to E. dunnii.

\section{Discussion}

Positive results were observed in all NPK dosages applied to the treatments for both E. benthamii and E. dunnii, highlighting the $167 \mathrm{~kg} \mathrm{ha}^{-1}$ treatment, in diameter, height, and volume. It can be noted that with the omission of NPK application, the variables also suffer a reduction in response. Cicek et al. [13] working with the effect of NPK fertilization on initial field performance with Fraxinus angustifolia (ash tree), with fertilization of $67 \mathrm{~g} \mathrm{plant}^{-1}$ NPK (10-10-10) and $133 \mathrm{~g} \mathrm{plant}^{-1}$ NPK (20-20-20), observed positive effects on increases in BHD and $\mathrm{H}$ during the first 36 months of growth, and when compared to the control (without fertilization), the averages were 24\% higher. Bavoso and Bassaco [14], in their work with E. dunnii growth with increasing doses of NPK, stated that the absence of NPK limited the development of plants, and in contrast, growth had a positive relationship with increasing dosage. This positive growth response is due to the greater amount of nutrients essential for the development of the plant that are available to be absorbed by it. The decrease in plant growth without initial fertilization, as observed in our study with both species of Eucalyptus, is a function of the participation of elements in the structure of numerous molecules, being the main limitation of growth, being part of proteins, nucleic acids, and many other cellular constituents, such as membranes and hormones [15]. 


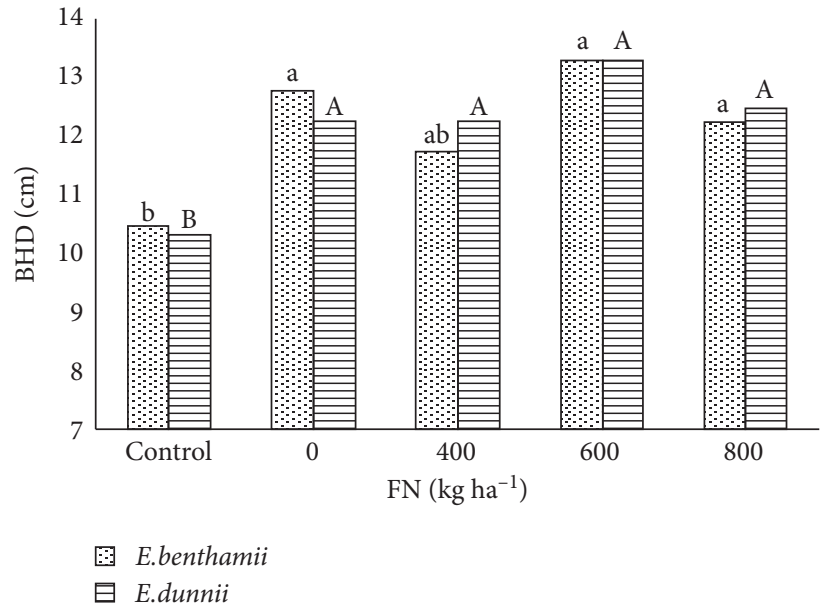

(a)

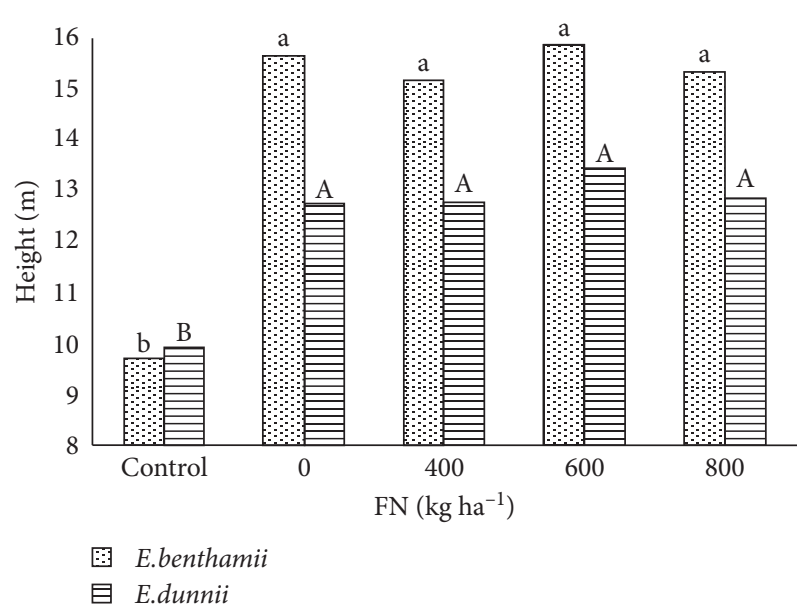

(b)

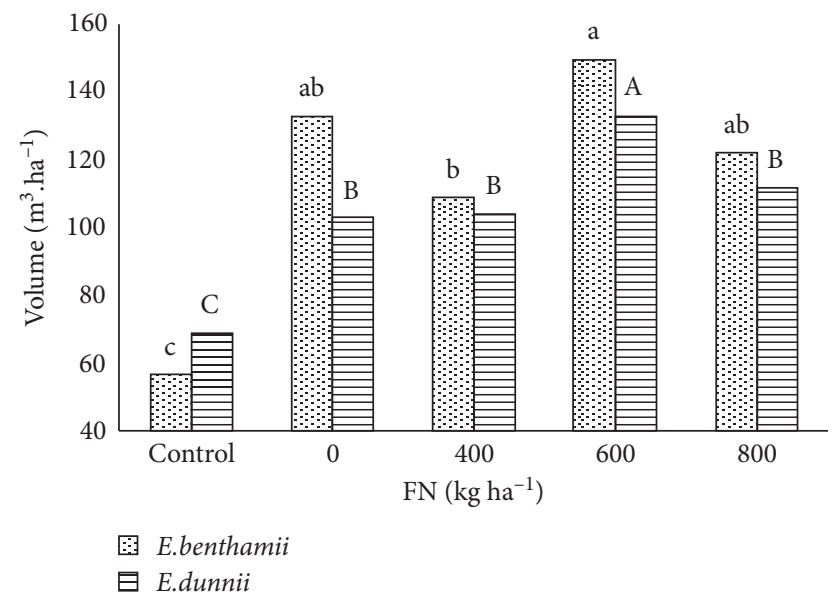

(c)

Figure 2: (a) Breast height diameter (BHD, $\mathrm{cm}$ ), (b) height (m), and (c) volume $\left(\mathrm{m}^{3} \mathrm{ha}^{-1}\right)$ in Eucalyptus benthamii and Eucalyptus dunnii in relation to natural phosphate (FN) fertilizing. Averages followed by the same letter, lower and uppercase, do not differ between them by the Tukey test at $5 \%$ probability. Lowercase letters compare fertilization in relation to E. benthamii. Uppercase letters compare fertilization in relation to E. dunnii.

Comparing the species, there is a difference in growth in relation to the variables height and volume. E. benthamii stands out with higher averages, and one of the possible explanations for the volume average to be higher is to be directly related to height, since the two species do not present differences in BHD. Moro et al. [16], in the study on response of Pinus taeda with different ages and NPK fertilization in the southern Santa Catarina plateau (Brazil), observed that the wood volume increased in all ages in response to NPK fertilization. According to the authors, adequate fertilization of the three chemical elements is important. Treatments that omitted some nutrients had lower volume averages.

Regarding the conditions of the present study, the positive response of mineral fertilization with NPK from the lowest doses can be explained by the low presence of $P$ and $K$ and O.M. content and clay (Table 1) in the soil, with data found by Muniz et al. [17] who consider that the amount of NPK fertilizer directly influences the development of
Eucalyptus change. According to Epstein and Bloom [18], the application of $P$ is necessary to guarantee the production and the ideal quality of the plants, when still young and when the root system is not yet developed to explore larger soil volume. There is a response of $\mathrm{K}$ in the growth for Eucalyptus species [19] stressing that its application to the study soil was extremely important. Since one of the main sources of $N$ in the soil comes from the O.M. contents, the application of this element may have been fundamental for the development of the planting in the study soil.

In treatments with natural phosphate (NP), a positive response of the averages above the control in BHD, height, and volume for both E. benthamii and E. dunnii can be observed at all applied doses. This may be related to the phosphorus $(P)$ requirement that Eucalyptus has in the stand implementation phase, being the highest critical $P$ level in the early development phase [3]. This response to $P$ is likely to decrease for both species over time, decreasing the influence of nutrient on growth. 


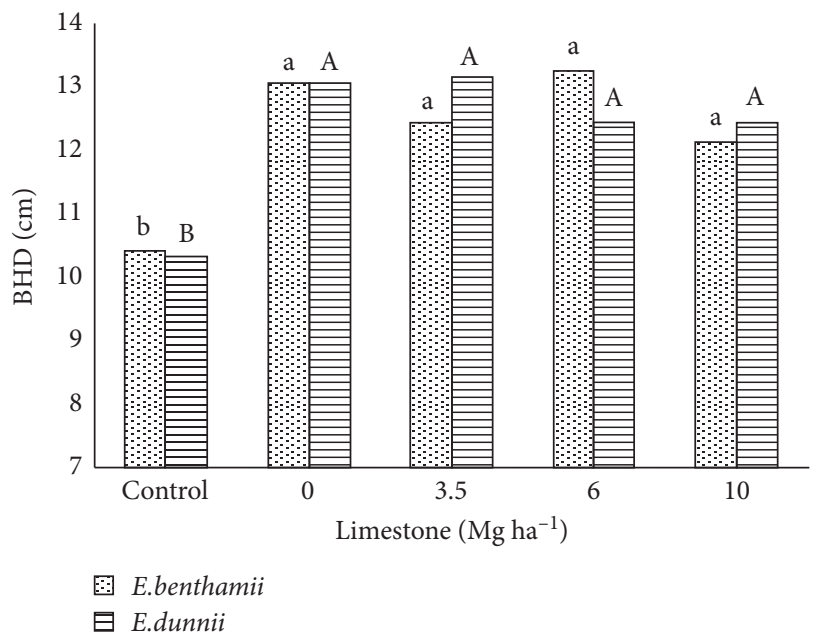

(a)

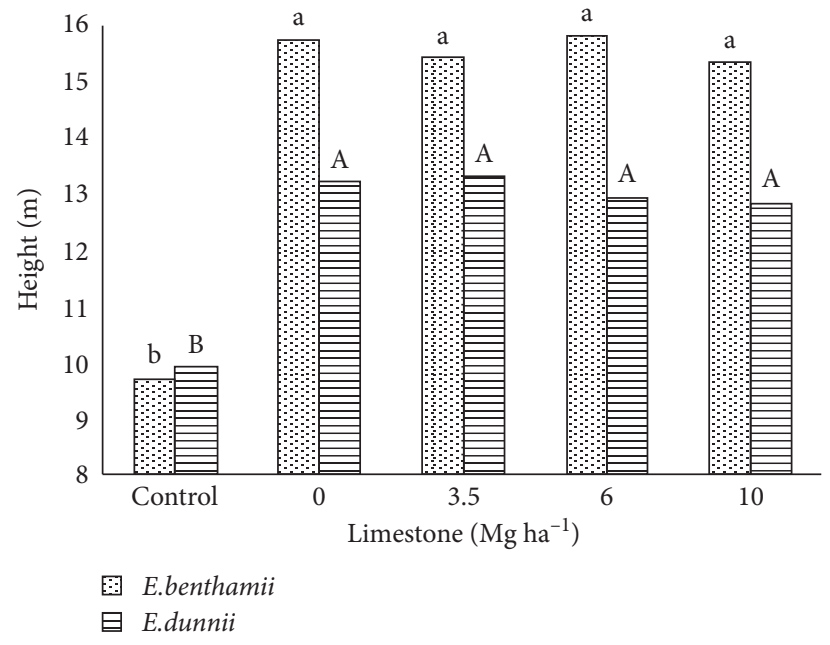

(b)

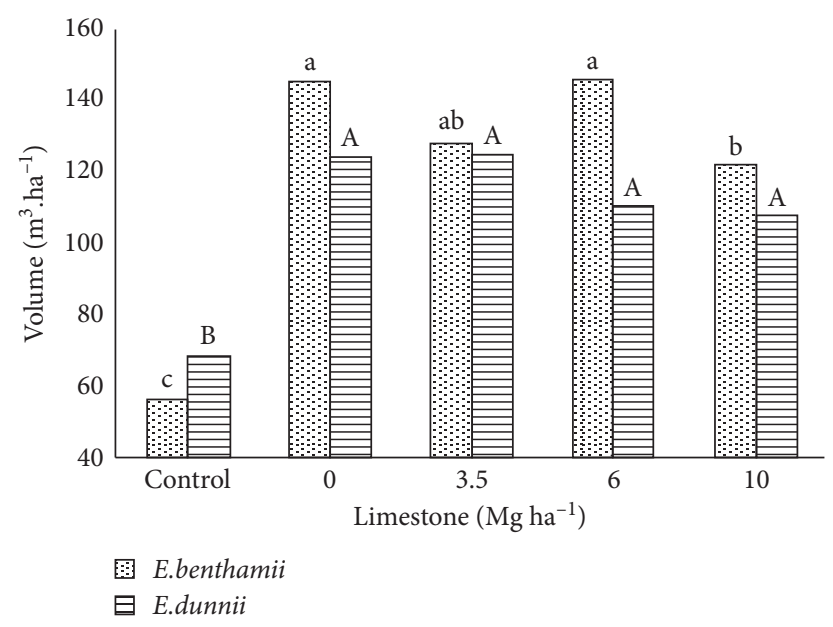

(c)

Figure 3: (a) Breast height diameter (BHD, $\mathrm{cm}),(\mathrm{b})$ height $(\mathrm{m})$, and (c) volume $\left(\mathrm{m}^{3} \mathrm{ha}^{-1}\right)$ in Eucalyptus benthamii and Eucalyptus dunnii in relation to liming. Averages followed by the same letter, lower and uppercase, do not differ between them by the Tukey test at $5 \%$ probability. Lowercase letters compare fertilization in relation to E. benthamii. Uppercase letters compare fertilization in relation to E. dunnii.

When comparing the species, E. benthamii stands out in height and volume, with no difference between the response for variable diameter. This behavior may be explained by the better response of $E$. benthamii to fertilization, while E. dunnii does not have such a strong but significant response.

Regarding liming, positive results were obtained at all dosages for E. benthamii and E. dunnii in relation to BHD and height, showing higher growth when compared to control, although the species is tolerant to soil acidity, as a function of low $\mathrm{pH}$. However, the fact that the treatments presented higher averages than the control may be related to the $\mathrm{Ca}$ and $\mathrm{Mg}$ supply through liming, favoring the species development. Tucci et al. [20] observed a significant effect on the growth of forest species with liming from the application of $0.75 \mathrm{Mg} \mathrm{ha}^{-1}$, also increasing $\mathrm{Ca}$ and $\mathrm{Mg}$ and decreasing Al content.

In the present study, there was also a positive relationship between the volume variable and liming. For both species, the treatments with limestone application were superior to the control, showing that liming positively affected the growth. In a similar study, Maeda and Bognola [21] obtained a liming effect on E. dunnii growth, increasing shoot dry matter production, seedling growth, accumulation, and $P$ use efficiency in Eucalyptus.

E. benthamii presented the highest averages of height and volume in the comparative between species, reinforcing the assumption that the response to fertilization of the species is higher when compared to E. dunnii. It can be said that under the conditions of the present study, fertilization was of supreme importance in plant growth, demonstrating that with the application of nutrients in the soil, the species responded to growth. This response may be directly related to $\mathrm{Ca}$ and $\mathrm{Mg}$ supply through liming and increase of $N, P$, and $K$ levels with NPK application and phosphate fertilization, factors that mainly contributed to the initial development and establishment of the plantation. 


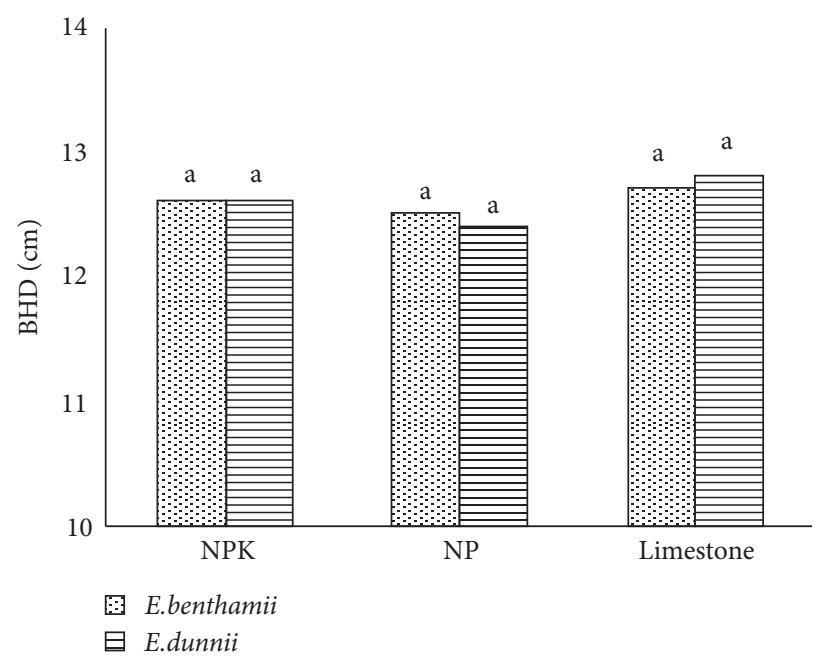

(a)

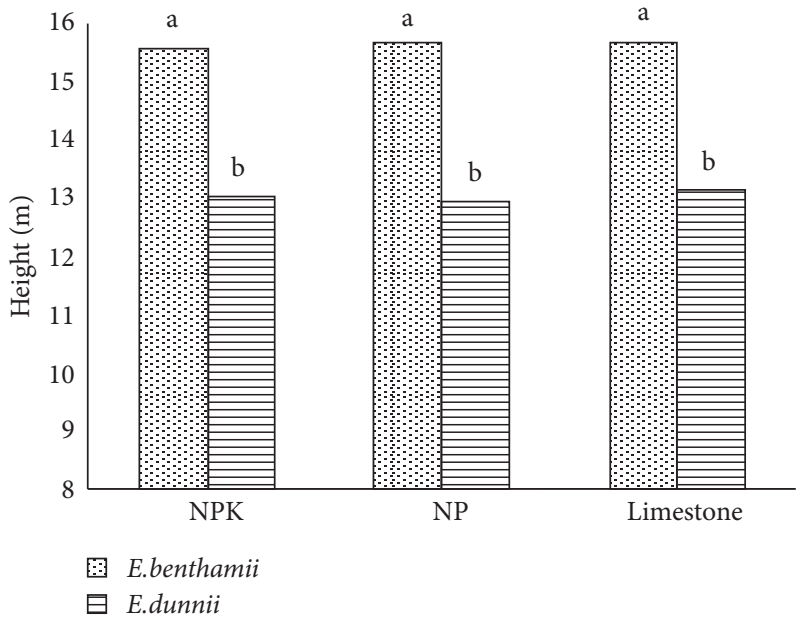

(b)

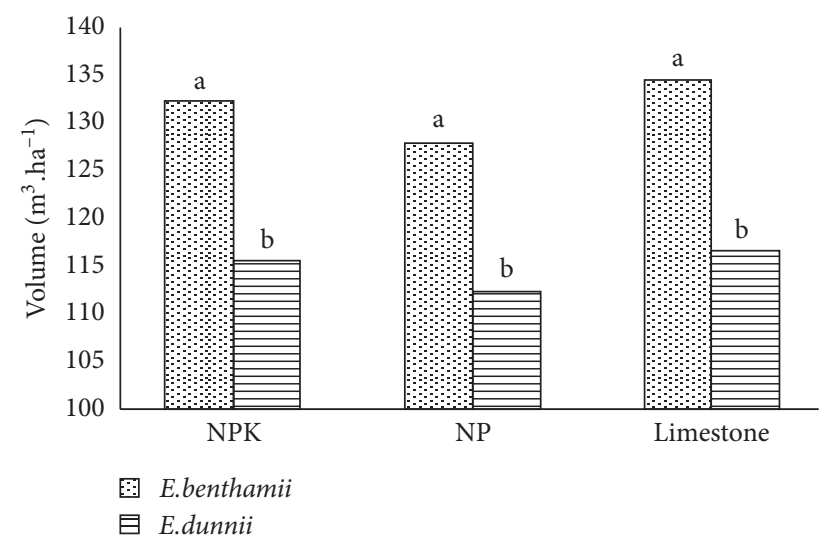

(c)

Figure 4: (a) Breast height diameter (BHD, cm), (b) height (m), and (c) volume $\left(\mathrm{m}^{3} \mathrm{ha}^{-1}\right.$ ) in Eucalyptus benthamii and Eucalyptus dunnii. Averages followed by the same letter, lower and uppercase, do not differ between them by the Tukey test at $5 \%$ probability. Lowercase letters compare fertilization in relation to E. benthamii. Uppercase letters compare fertilization in relation to E. dunnii.

Maximum growth limiting doses were not found for the studied species, but unnecessary liming may affect the availability of other nutrients and cause restrictions on plant growth, also increasing production costs.

\section{Conclusions}

For NPK, the recommendation is $167 \mathrm{~kg} \mathrm{ha}^{-1}$, which presented the highest growth averages for all variables.

For NP, the recommendation is $600 \mathrm{~kg} \mathrm{ha}^{-1}$, which is the dosage that presented the growth peak of the study variables.

For limestone, the dose application recommendation is $3.5 \mathrm{Mg} \mathrm{ha}^{-1}$, aiming to supply the $\mathrm{Ca}$ and $\mathrm{Mg}$ amounts in the soil.

E. benthamii has the higher demand for NP, NPK fertilization, and liming than E. dunnii.

\section{Data Availability}

The data used to support the findings of this study are available upon request from the corresponding author.

\section{Conflicts of Interest}

The authors declare that there are no conflicts of interest regarding the publication of this paper.

\section{Acknowledgments}

The authors acknowledge the University of the State of Santa Catarina (UDESC) for the institutional support for conducting the master's research in Forest Engineering by Diego Pereira da Rosa (first author of the article), with a 
dissertation entitled "Calagem e adubação no crescimento de Eucalyptus benthamii Maiden et. Cambage e Eucalyptus dunnii Maiden." They would also like to acknowledge FAPESC for funding the research group Management of Planted and Natural Forests (PAP2019031000055) and Coordenação de Aperfeiçoamento de Pessoal de Nível Superior (CAPES) for partial finance support, Brazil (Finance code 001). They also thank the company Souza Cruz ${ }^{\circledR}$.

\section{References}

[1] A. C. Davide and J. M. R. Faria, "Viveiros florestais," in Davide AC, Silva EAA. Produção de sementes e mudas de espécies florestais, pp. 83-124, Universidade Federal de Lavras, Lavras, Brazil, 2018.

[2] J. L. M. Gonçalves, B. Raij, and J. C. Gonçalves, "Florestais," in Furlani AMC. Recomendações de adubação e calagem para o Estado de São Paulo. Campinas, B. van Raij, H. Cantarella, and J. A. Quaggio, Eds., pp. 245-259, Instituto Agronômico de Campinas e Fundação IAC, São Paulo, Brazil, 1996.

[3] L. P. R. Dias, L. C. Gatiboni, G. Brunetto, M. A. Simonete, and B. Bicaratto, "Eficiência relativa de fosfatos naturais na adubação de plantio de mudas de eucalyptus dunnii maiden e eucalyptus benthamii maiden et cambage em solo sem e com calagem," Ciencia Florestal, vol. 25, no. 1, pp. 37-48, 2015.

[4] C. R. S. Sette Jr., M. T. Filho, J. L. Lousada, and J. P. Laclau, "Efeito da aplicação de fertilização nitrogenada e lodo de esgoto nas características da madeira juvenil de árvores de eucalyptus grandis," Cerne, vol. 15, no. 3, pp. 303-312, 2009.

[5] T. L. Factor, P. E. Trani, J. M. Breda, L. F. V. Purquerio, and L. C. Grangeiro, "Correção do solo e adubação," in Cebola Do Plantio a Colheita, C. Nick and A. Borém, Eds., pp. 58-77, UFV, Lavras, Brazil, 2018.

[6] N. F. Barros, R. F. Novais, and J. C. L. Neves, "Fertilização e correção do solo para o plantio de eucalipto," in Relação SoloEucalipto, N. F. Barros and R. F. Novais, Eds., pp. 127-186, Folha de Viçosa, Viçosa, Brazil, 1990.

[7] R. C. Santana, N. F. Barros, R. F. Novais, H. G. Leite, and N. B. Comerford, "Alocação de nutrientes em plantios de eucalipto no Brasil," Revista Brasileira de Ciência do Solo, vol. 32, no. 1, pp. 2723-2733, 2008.

[8] EPAGRI/CIRAM, Zoneamento Agroecológico, EPAGRI/ CIRAM, Florianópolis, Brazil, 2018, http://ciram.epagri.rctsc.br/portal/website/index.jsp?url=jsp/agricultura/ zoneAgroecologico.jsp\&tipo=agricultura\%3e.

[9] I. R. Calder, R. L. Hall, and P. G. Adlard, Growth and Water Use of Forest Plantations, John-Wiley, Chichester, UK, 1992.

[10] M. J. Tedesco, C. Gianello, C. A. Bissani, H. Bohnen, and S. J. Volkweiss, Análise de solo, plantas e outros materiais, UFRGS, Porto Alegre, Brazil, 1995.

[11] CQFS RS/SC, Manual de calagem e adubação para os Estados do Rio Grande do Sul e de Santa Catarina, SBCS, Porto Alegre, Brazil, 2016.

[12] D. L. C. Miranda, V. B. Junior, and D. M. Gouveia, "Fator de forma e equações de volume para estimativa volumétrica de árvores em plantio de Eucalyptus urograndis," Scientia Plena, vol. 11, no. 3, pp. 1-8, 2015.

[13] E. Cicek, F. Yilmaz, and M. Yilmaz, "Effect of N and NPK fertilizers on early field performance of narrow-leaved ash, fraxinus angustifolia," Journal of Environmental Biology, vol. 31, no. 1, pp. 109-114, 2010.

[14] F. Bavoso and M. V. M. Bassaco, "Comparação do crescimento de eucalyptus dunnii em doses crescentes de adubação
(NPK)," Revista da União Latino-americana de Tecnologia, vol. 1, no. 2, pp. 38-52, 2014.

[15] S. R. Souza and M. S. Fernandes, "Nitrogênio," in Nutrição Mineral de Plantas, M. S. Fernandes, Ed., pp. 215-252, Sociedade Brasileira de Ciência do Solo, Viçosa, Brazil, 2016.

[16] L. Moro, L. C. Gatiboni, M. A. Simonete, P. C. Cassol, and D. M. Chaves, "Resposta de pinus taeda com diferentes idades à adubação NPK no Planalto Sul Catarinense," Revista Brasileira de Ciência do Solo, vol. 38, no. 4, pp. 1181-1189, 2014.

[17] C. O. Muniz, L. M. Lôbo, F. P. R. Fernandes, E. M. Ferreira, and E. P. F. Brasil, "Efeito de diferentes adubos NPK no processo de produção de mudas de eucalipto," Encyclopedia of the Biosphere, vol. 9, no. 17, pp. 1162-1168, 2013.

[18] E. Epstein and A. J. Bloom, Mineral Nutrition of Plants: Principles and Perspectives, Sinauer Associates, Sunderland, MA, USA, 2nd edition, 2005.

[19] C. R. Sette Jr., M. T. Filho, C. T. S. Dias, and J. P. Laclau, "Crescimento em diâmetro do tronco das árvores de eucalyptus grandis W. Hill. Ex. Maiden e relação com as variáveis climáticas e fertilização mineral," Revista Árvore, vol. 34, no. 6, pp. 979-990, 2010.

[20] C. A. F. Tucci, H. N. Lima, A. d. S. Gama, H. S. Costa, and P. A. d. Souza, "Efeitos de doses crescentes de calcário em solo latossolo amarelo na produção de mudas de pau-de-balsa (ochroma lagopus sw., bombacaceae)," Acta Amazonica, vol. 40, no. 3, pp. 543-548, 2010.

[21] S. Maeda and I. A. Bognola, "Efeito da calagem, do fosfato natural de Gafsa e superfosfato triplo no crescimento inicial e absorção de P em Eucalyptus dunnii," Pesquisa Florestal Brasileira, vol. 31, no. 68, pp. 355-361, 2011. 